\title{
X-ray powder diffraction analysis of methionine sulfoxide
}

Pedro P. Corbia)

Departamento de Química Geral e Inorgânica, Instituto de Química-UNESP, P.O. Box 355, 14801-970,

Rua Professor Francisco Degni, s/n, Araraquara, SP, Brazil

Petr Melnikov

CCET-UFMS, Centro de Ciências e Tecnologia, P.O. Box 549, 79070-900 Cidade Universitária, s/n, Campo Grande, MS, Brazil

Antonio C. Massabni

Departmento de Química Geral e Inorgânica, Instituto de Química-UNESP, P.O. Box 355, 14801-970,

Rua Professor Francisco Degni, s/n, Araraquara, SP, Brazil

(Received 4 February 2001; accepted 19 March 2001)

Powder X-ray diffraction data for methionine sulfoxide, $\mathrm{C}_{5} \mathrm{H}_{11} \mathrm{NO}_{3} \mathrm{~S}$, obtained from the commercial amino acid, are presented in this work. Monoclinic cell parameters are: $a=15.500 \AA ; b$ $=3.820 \AA ; c=13.490 \AA ; \beta=97.300^{\circ}$. (C) 2001 International Centre for Diffraction Data.

[DOI: $10.1154 / 1.1383081]$

Key words: powder diffraction, amino acid, methionine sulfoxide

\section{INTRODUCTION}

Methionine sulfoxide (MetSO, $\mathrm{C}_{5} \mathrm{H}_{11} \mathrm{NO}_{3} \mathrm{~S}$, Figure 1), a product of vegetal origin, is an amino acid similar to methionine. It is present in garlic (Sugii et al., 1964), onion (Kuon and Bernhard, 1963), nut (Kristensen et al., 1974), carrot (Alabran and Mabrouk, 1973), apple (BielinskaCzarnecka, 1963; McKee and Urbach, 1953), and banana plant (Steward et al., 1960). Recently, methionine sulfoxide was shown to be associated with Alzheimer's disease, due to glutamine synthetase inhibition. This process is accomplished through a free radical oxidation stress. Therefore, the compound is considered a biological sensor for such transformation (Chao et al., 1997; Haghighi and Maples, 1996). This amino acid, readily available and of low cost, was also shown to possess pronounced antiinflammatory effects (Unnikrishnan and Rao, 1990). In this context, the ligand and its transition metal complexes are of interest for research in order to obtain virtual chemical vehicles for safer drugs, pharmaceutical trappers, or even antidotes for the cases of acute poisonings. Metal (II) complexes of the first transition series involving DL-methionine-sulfoxide have been studied in our laboratories recently (Corbi $e t$ al., 2000). The present work is dedicated to the characterization of the amino acid methionine sulfoxide by using X-ray powder diffractometry.

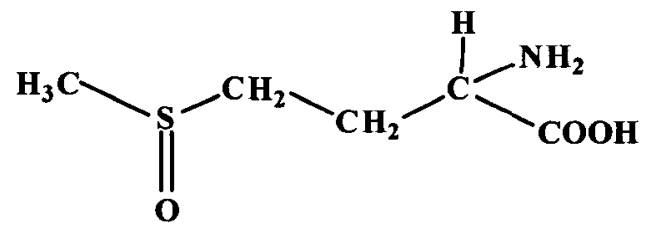

Figure 1. Schematic representation of methionine sulfoxide.

a`Electronic mail: pedrocorbi@yahoo.com

\section{EXPERIMENT}

Powder microcrystalline methionine sulfoxide was obtained from a Sigma commercial product by recrystalization. The fine powder product was dried under $\mathrm{P}_{4} \mathrm{O}_{10}$ in a dessicator for two days and, after trituration, the amino acid was analyzed by using powder X-ray diffratometry and density measurements.

\section{INSTRUMENTAL CONDITIONS}

The powder was tested in a Siemens D 5000 Diffractometer using $\mathrm{Cu} K \alpha$ radiation $(\lambda=1.5418 \AA)$ with a graphite diffracted beam monochromator. The sample was scanned over the $2 \theta$ range from $4^{\circ}$ to $70^{\circ}$ in $0.05^{\circ}$ steps. The counting time was $2.0 \mathrm{~s} / \mathrm{step}$.

Density measurements were performed by using the Pycnometer ACCPYC 1330 Micromeritics instrument.

\section{RESULTS AND DISCUSSION}

Elemental analysis for $\mathrm{C}, \mathrm{H}$, and $\mathrm{N}$ was carried out by using a CHNS-O EA 1110 Analyzer, CE Instruments. The data reported in Table $I$ fit to the required formula $\mathrm{C}_{5} \mathrm{H}_{\mathrm{II}} \mathrm{NO}_{3} \mathrm{~S}$.

A powder X-ray diffractogram of methionine sulfoxide is shown in Figure 2.

The indexation of the experimental X-ray powder diffraction data for methionine sulfoxide was performed by considering a notable structural resemblance of this compound to the monoclinic form of the amino acid L-methionine (Powder diffraction file database, 1994). The

TABLE I. Elemental analysis for methionine sulfoxide.

\begin{tabular}{ccc}
\hline Elements & Calc. (wt \%) & Found (wt \%) \\
\hline $\mathrm{C}$ & 36.34 & 36.22 \\
$\mathrm{H}$ & 6.73 & 5.44 \\
$\mathrm{~N}$ & 8.48 & 8.42 \\
\hline
\end{tabular}




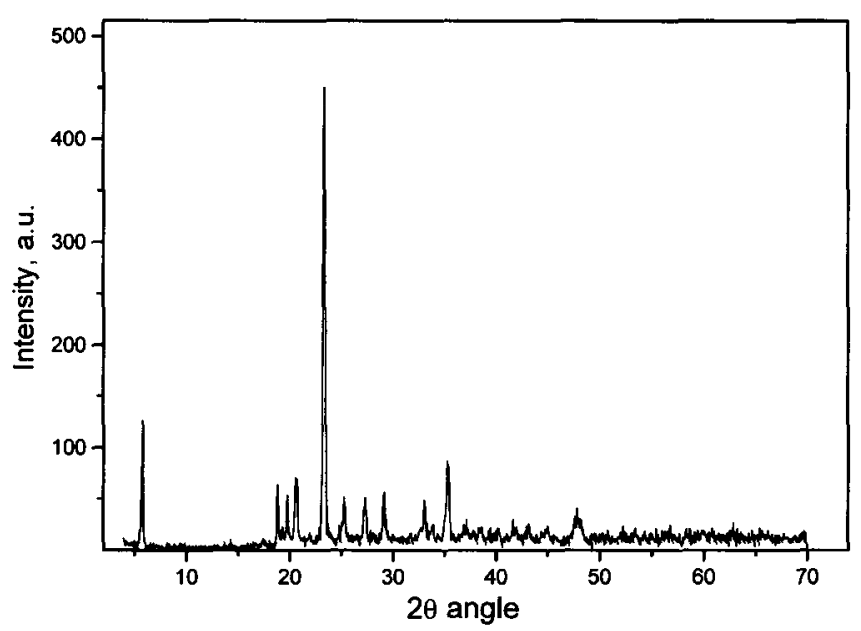

Figure 2. X-ray diffractogram of methionine sulfoxide.

known data for L-methionine permitted us to choose the primary parameters for methionine sulfoxide, which, after refining, by a least-squares approach, led to the following lattice parameters: $a=15.50 \AA ; \quad b=3.82 \AA ; \quad c=13.49 \AA$; $\beta=97.3^{\circ}$. The resulting indexation is shown in Table II.

TABLE II. X-ray diffractometry data for methionine sulfoxide (variation $\pm 0.05 \AA)$

\begin{tabular}{rrrrrr}
\hline \hline$I / I_{0}$ & $h$ & $k$ & $l$ & $d_{\text {obs. }}(\AA)$ & $d_{\text {calc. }}(\AA)$ \\
\hline 16 & 1 & 0 & 0 & 15.42 & 15.374 \\
3 & 3 & 0 & 0 & 5.10 & 5.125 \\
34 & 2 & 0 & 2 & 4.71 & 4.756 \\
13 & 3 & 0 & 1 & 4.59 & 4.595 \\
28 & 0 & 0 & 3 & 4.50 & 4.460 \\
34 & 3 & 0 & 5 & 4.31 & 4.344 \\
5 & 2 & 0 & $\overline{3}$ & 4.07 & 4.090 \\
100 & 0 & 1 & 0 & 3.82 & 3.820 \\
15 & 4 & 0 & $\overline{2}$ & 3.53 & 3.532 \\
20 & 2 & 1 & 1 & 3.28 & 3.270 \\
18 & 3 & 1 & 0 & 3.07 & 3.063 \\
19 & 4 & 1 & 0 & 2.71 & 2.709 \\
9 & 3 & 0 & 4 & 2.65 & 2.651 \\
27 & 6 & 0 & 0 & 2.54 & 2.562 \\
9 & 5 & 1 & $\overline{1}$ & 2.40 & 2.399 \\
10 & 3 & 0 & 5 & 2.27 & 2.257 \\
9 & 1 & 0 & 6 & 2.17 & 2.168 \\
9 & 3 & 1 & 5 & 2.09 & 2.096 \\
10 & 4 & 1 & 4 & 2.02 & 2.019 \\
14 & 7 & 1 & 0 & 1.91 & 1.904 \\
7 & 3 & 2 & 0 & 1.79 & 1.790 \\
9 & 8 & 1 & 0 & 1.72 & 1.717 \\
9 & 7 & 1 & 4 & 1.58 & 1.582 \\
13 & 11 & 0 & $\overline{1}$ & 1.41 & 1.409 \\
\hline \hline
\end{tabular}

Density measurements (pycnometric determination under helium, after a careful evacuation) permitted us to determine an experimental density of $1.472 \mathrm{~g} / \mathrm{cm}^{3}$. This experimental value, combined with the molecular weight of this amino acid, permitted us to calculate the number of formula weights contained in a cell, equal to $4(Z=4)$.

The results of the above-mentioned indexation show that essential structural features of the prototype amino acid L-methionine are mainly maintained in methionine sulfoxide, in contrast to the sharp differences in the network of their salts. It may be due to the absence of steric impediments brought by an additional functional group.

\section{CONCLUSION}

$\mathrm{X}$-ray diffraction data of methionine sulfoxide has been successfully indexed by its chemical similarity with L-methionine. The latter can be considered as a structural model on which its derivatives may be patterned.

\section{ACKNOWLEDGMENTS}

The authors are indebted to FAPESP, CNPq, and FAPEC for financial support (Brazilian agencies).

Alabran, D. A., and Mabrouk, A. F. (1973). "Carrot flavor. Sugars and free nitrogenous compounds in fresh carrots," J. Agric. Food Chem. 21, 205-208.

Bielinska-Czarnecka, M. (1963). "Ninhydrin-reacting substances from apple spurs," J. Sci. Food. Agric. 14, 527-528.

Chao, C. C., Ma, Y. S., and Stadtman, E. R. (1997). "Modification of protein surface hydrophobicity and methionine oxidation by oxidative systems," Proc. Natl. Acad. Sci. U.S.A. 94, 2969-2974.

Corbi, P. P., Melnikov, P., and Massabni, A. C. (2000). "A solid nickel (II) complex with methionine sulfoxide," J. Alloys Compd. 308, 153-157.

Haghighi, A. Z., and Maples, K. R. (1996), "On the mechanism of inhibition of glutamine synthetase and creatine phosphokinase by methionine sulfoxide," J. Neurosci. Res. 43, 107-111.

Kristensen, I., Larsen, P. O., and Soerensen, H. (1974). "Free amino acids and $\gamma$-glutamyl peptides in seeds of Fagus silvatica," Photochemistry 13, 2803-2811.

Kuon, J., and Bernhard, R. A. (1963). "Free amino acids in common onion," J. Food. Sci. 28, 298-304.

McKee, H. S., and Urbach, G. E. (1953). "The physiology of growth in apple fruits," Australian J. Biol. Sci. 6, 369--378.

Powder Diffraction File Database (1994). 23-1769 (JCPDS-ICDD).

Steward, P. C., Hulme, A. C., Freiberg, S. R., Hegarty, M. P., Pollard, J. R., Rabson, R., and Bar, R. A. (1960). "Physiological investigations on the banana plant. I. Biochemical constituents detected in the banana plant," Ann. Bot. (London) 24, 83-116.

Sugii, M., Suzuki, T., Kakimoto, T., and Kato, J. (1964), "Sulfur containing amino acids and related compounds in garlic. I. Assimilation of sulfate ${ }^{35} \mathrm{~S}$ in garlic," Bull. Inst. Chem. Res., Kyoto Univ. 42, 246-251.

Unnikrishnan, M. K., and Rao, M. N. A. (1990). "Anti-inflammatory activity of methionine, methionine sulfoxide and methionine sulfone." Agents Actions 31, 110-112. 